\begin{tabular}{cc}
\hline \hline \\
(Bisnis dan Manajemen) $\begin{array}{c}\text { Volume Issue 2, April 2020, 88-106 } \\
\text { ISSN 2549-7790 (Online) } \\
\text { ISSN 1979-7192 (Print) } \\
\text { DOI: 10.26740/bisma.v12n2.p88-106 } \\
\text { https://journal.unesa.ac.id/index.php/bisma/index }\end{array}$ \\
\hline \hline
\end{tabular}

\title{
Analysis of factors affecting adoption of mobile banking application in Indonesia: an application of the unified theory of acceptance and use of technology (UTAUT2)
}

\author{
Mufingatun Mufingatun $^{1^{*}}$, Budi Prijanto ${ }^{2}$, and Himanshu Dutt ${ }^{3}$ \\ ${ }^{1}$ Department of Information System Management, Post-graduate Program, \\ Gunadarma University \\ Jalan Margonda Raya No.100, Depok, Jawa Barat 16424, Indonesia \\ fiaaopi@gmail.com \\ ${ }^{2}$ Department of Accounting, Faculty of Economy, Gunadarma University \\ Jalan Margonda Raya No.100, Depok, Jawa Barat 16424, Indonesia \\ karami@staff.gunadarma.ac.id \\ ${ }^{3}$ Visiting Faculty, Centre for Management Studies, Jamia Milia Islamia \\ Jamia Nagar, Okhla, New Delhi 110025, India \\ himanshudutt@gmail.com
}

\begin{abstract}
Information technology has made mobile banking easy, convenient and accessible to 178 million unique mobile subscribers base in Indonesia. Out of this 50 million are smartphone users and collectively about 132 million are internet users. This rising trend has been forcing 120 commercial banks in the country to ramp up their mobile-based banking initiatives. However, in contrast to it, only 50 million have bank accounts out of 250 million Indonesian population size . This poses a few challenges to digital adoption using mobile as medium, especially when a limited number of people have bank accounts and the cost of internet is high due to geographical, infrastructural spread and cost barriers. The purpose of this study is to unearth such factors that have - direct or indirect influence on consumer acceptance for mobile banking applications. This research model examines 205 respondents from online surveys in Jabodetabek, Indonesia. To conduct this study, we have used Unified Theory of Acceptance and Use of Technology (UTAUT2) model that helps in understanding perceived credibility and perceived selfefficacy variables and their roles in influencing the adoption for m-banking. Data was analysed using Partial Least Square (PLS) method. The findings suggest that performance expectancy, effort expectancy, and social influence have a significant effect on behavioral

\section{How to cite this document:}

Mufingatun, Prijanto, B., \& Dutt, H. (2020). Analysis of factors affecting adoption of mobile banking application in Indonesia: an application of the unified theory of acceptance and use of technology (UTAUT2). BISMA (Bisnis dan Manajemen), 12(April), 88-106. https://doi.org/10.26740/bisma.v12n2.p88-106
\end{abstract}


Page 88-106

intention. Performance expectancy is the factor that mostly influences behavior intention. It can also be stated that behavioral intention, facilitating condition and habit - all of these have a significant effect on reuse behavior.

Keywords: mobile banking; perceived credibility; perceived self-efficacy; UTAUT2.

Received: January 4, 2020; Accepted: February 10, 2020; Published: April 3, 2020

*Corresponding author

Email: fiaaopi@gmail.com

\section{Abstrak}

Teknologi informasi memberikan kemudahan, kenyamanan dalam penggunaan mobile banking dan dapat diakses oleh 178 juta pelanggan seluler di Indonesia. Dengan komposisi 50 juta pengguna smartphone dan 132 juta pengguna internet. Tren yang meningkat ini membuat 120 bank komersial di negara ini untuk meningkatkan inisiatif perbankan berbasis mobile. Namun, berbeda dengan itu, hanya 50 juta yang mempunyai rekening bank dari 250 juta jumlah penduduk Indonesia. Hal ini menimbulkan beberapa tantangan untuk mengadopsi digital dengan menggunakan ponsel sebagai media, terutama ketika beberapa orang mempunyai rekening bank namun biaya internet yang tinggi karena geografis, penyebaran infastruktur dan hambatan biaya. Tujuan dari penelitian ini adalah untuk mencari faktor-faktor yang mempunyai pengaruh langsung atau tidak langsung pada penerimaan konsumen untuk aplikasi mobile banking. Model penelitian ini diuji dengan menggunakan 205 responden dari survei online di wilayah Jabodetabek, Indonesia. Untuk melakukan penelitian ini, kami menggunakan model Unified Theory of Acceptance dan Use of Technology (UTAUT2) yang membantu dalam memahami varibel perceived credibility dan perceived self-efficacy dan peran variabel tersebut dalam memengaruhi adopsi m-banking. Data dianalisis menggunakan Partial Least Square (PLS). Hasil penelitian menunjukkan bahwa performance expectancy, effort expectancy, dan social influence berpengaruh signifikan terhadap behavioral intention. Performance expectancy merupakan factor yang paling memengaruhi behavioural intention. Dapat dinyatakan bahwa behavioral intention, facilitating condition, dan habit - semua variable tersebut berpengaruh signifikan terhadap reuse behavior.

Kata kunci: mobile banking; persepsi kredibilitas; persepsi self-efficacy; UTAUT2.

\section{INTRODUCTION}

The development of information technology improves mobile devices such as smartphones, notebooks, netbooks and tablet computers with a network of $3 \mathrm{G}$ and $4 \mathrm{G}$ internet connections. Indonesia's population of 251 million is the country with the largest smartphone users in the world (Rema and Steyohadi, 2016). According to data from Emarketer in 2014, it is estimated that by 2018 the number of active smartphone users in Indonesia will be more than 100 users. Indonesia becomes the country with the fourth largest active smartphone users in 
the world after China, India, and America (Rahmayani, 2015).

The use of mobile devices increases rapidly and encourages many service sectors to integrate their financial service with the internet-based mobile device. This encourages banking businesses to provide mobile banking service applications to provide easier, more convenient, faster, anytime, and anywhere financial services for the customer. This application will enable the customer to conduct financial transactions and access information securely (Putra, 2015).

In Indonesia, the practice of internet banking was introduced by BII (PT Bank Internasional Indonesia, Tbk) in 1988 with an application called BII Internet Banking. After that, it was followed by BCA (PT Bank Central Asia, Tbk) on March 20, 2001, with the KlikBCA application. Then on April 26, 2001, Bank Niaga (PT Bank Niaga, Tb) launched an application called Niaga Global@cess. The use of mobile banking is for facilitating customer transactions as well as becoming information technology in influencing the efficiency and effectiveness of the banking business. With the presence of mobile banking, the human error in conducting financial services by bank tellers when processing cash transactions can be minimized (Ferdiansyah and Handayani, 2011).

According to the results of the MARS Indonesia survey institute in 2013, bank customers' penetration or mobile banking usage rates reached $41.2 \%$. There are still around $58.8 \%$ of customers who stated that they do not have a mobile banking account. The survey results increased by $23.6 \%$ compared to the results of the survey in 2008 that concluded the penetration of mobile banking accounts for only $17.6 \%$ (MARS Indonesia Newsletter, 2013). However, according to the research institute Microsave, the internet users of financial services in Indonesia were only $0.73 \%$ of the total cellular phone users, the percentage was relatively small compared to Malaysia, which was $5.79 \%$ (Tempo, 2016).

This phenomenon is caused by the habit of Indonesian people who prefer using cash as their transaction method. It implies that current technological developments cannot directly change people's lifestyles (Tarhini et al., 2016). One of the factors that make people prefer cash transactions is that they are not yet accustomed to using smartphones and concerned about the security factor. Hence, the security factor is still becoming the main consideration for people to make non-cash transactions (Nugroho et al., 2017).

According to Pertiwi and Ariyanto (2017), one of the causes of the number of customers who have not adopted mobile banking even though many benefits will be obtained is the lack of socialization by the bank to them. Hartono in Pertiwi and Ariyanto (2017) states that there are still many people who experience failure in the application of an information system even though the quality of the system technique has increased.

Therefore, this study aims to know the acceptability of mobile banking applications from the user's perspective so that they can be used as a reference for 
customers who do not have and use mobile banking applications. Besides, it can also be used as a means to improve organizational performance, especially in banking institutions. This study is based on the identification of factors in the Unified Theory of Acceptance and Use of Technology (UTAUT2) model with the addition of variables perceived credibility and perceived self-efficacy.

The data is collected from customers who have used the mobile banking application in the area Jabodetabek (Jakarta, Bogor, Depok, Tangerang, and Bekasi) Indonesia. It is because Jabodetabek is the biggest internet users in Indonesia. According to the results of a survey conducted by the Indonesian Internet Service Providers Association (APJII, 2016), the majority of internet users in Indonesia were on Java with a total user of 86,339,350 users or around $65 \%$ of the total internet usage (APJII, 2016). Therefore, the Jabodetabek area is representative in reflecting the interests and behavior of using mobile banking.

\section{Mobile Banking}

According to Otoritas Jasa Keuangan (2015), the definition of mobile banking is a service that allows bank customers to conduct banking transactions via a smartphone. Mobile banking offers convenience when compared to SMS banking because customers do not need to remember the SMS message format that will be sent to the bank and the SMS banking destination number. The mobile banking service is regulated in a Bank Indonesia Regulation No.9/15/PBI/2007 Year 2007 concerning Application of Risk Management in the Use of Information Technology by Commercial Banks and also contained in UU No. 11 the Year 2008 about Information and Electronic Transactions (Pertiwi and Ariyanto, 2017).

The Bank continues to renew its technology and improve so that it can reach all of their customers. One of the advantages of using mobile banking is that people in rural or remote areas can also access mobile banking easily, whenever needed (Nayak, et al., 2014). Moreover, another advantage is the confidentiality of user IDs that are not easily known by other parties (Pertiwi and Ariyanto, 2017).

\section{Unified Theory of Acceptance and Use of Technology 2}

The UTAUT model is one of the latest technology acceptance models developed by Venkatesh, et al (2003). The construct is performance expectance, effort expectance, social influence, facilitating conditions, attitude toward using technology, and self-efficacy. Venkatesh with Thong and Xu (2012) found a new model called UTAUT 2 by combining three new constructs from the previous UTAUT model, namely: (1) hedonic motivation (2) price value (3) habit. The use of UTAUT2 in this study based on empirical evidence has been shown to provide an overview of the user's intent to use information systems and individual usage behaviors (Bhimasta, 2017). 
The purpose of the UTAUT2 model is (1) to identify three important constructs of research in the use and acceptance of both public and consumers, (2) to change some of the existing relationships in the concept of the UTAUT model, and (3) to introduce new relationships (Venkatesh et al., 2012).

\section{Performance Expectancy}

Performance expectations are similar to the perceived usefulness of TAM / TAM2, the relative advantage of IDT, and outcome expectations of SCT (Kit et al., 2014). Performance expectations reflect the extent to which someone believes that using mobile banking will provide benefits in carrying out banking activities (Venkatesh et al., 2003). Performance expectations are expected to be one of the most important factors that directly affect acceptance intentions (Baptista and Tiago, 2015). Previous research (Nugroho et al., 2017; AbuShanabet al., 2010; Venkatesh.et al., 2012; Azis and Kamal, 2016) explained that performance expectations are strong variables that influence interest in using mobile banking. Accordingly, this study formulates hypothesis as follows:

H1: Performance expectancy significantly affects the behavioral intention to use mobile banking.

\section{Effort Expectancy}

In UTAUT, business expectations have a perceived easy to use from TAM, complexity from MPCU and ease of use at IDT (Venkatesh et al., 2003). According to Rema and Setyohadi (2016) that business expectations or business expectations according to UTAUT explain the user's perceptions of the level of ease associated with the use of a system so that it relates to the ease of learning in using or skilled in using mobile banking. When users feel that mobile banking is easy to use and doesn't require much effort, they have high expectations for the expected performance (Nugroho et al., 2017).

In previous studies, they are (Rema and Setyohadi, 2016; Abushanab et al, 2010; Foon and Fah, 2011; Kit et al., 2014; and Azis and Kamal, 2016) discussed that business expectations affect the interest in using mobile banking. Accordingly, this study formulates hypothesis as follows:

$\mathrm{H} 2$ : Effort expectancy significantly affects behavioral intention to use mobile banking.

Social Influence

Social influence on UTAUT2 is similar to subjective norms of the TRA, TAM2, TBP / DTBP models, TAM + TPB, social factors of MPCU, and the image of IDT. According to Nugroho et al., (2017) the use of certain technologies is influenced by environmental factors such as the opinions of friends and family who use the technology. With a positive opinion or support, it will encourage users to start using the technology. Previous research ( $\underline{\mathrm{Yu}, 2012}$; AbuShanab et 
al.,2010; Foon and Fah, 2011; and Azis and Kamal, 2016) also explained that social influence influences the interest in using mobile banking. Accordingly, this study formulates hypothesis as follows.

H3: Social influence significantly affects behavioral intention to use mobile banking.

Price/Value

Baptista and Tiago (2015) add factors such as data service operator fees, namely the mobile Internet, device fees, service fees and transaction fees that influence the behavioral intention to use mobile banking. When consumers receive the benefits of using mobile that greater than the costs incurred, consumers tend to use mobile banking regularly (Nugroho et al., 2017).

The price value variables influence interest in using technology to adopt mobile banking (Pertiwi and Arianto, 2017; and Baptista and Tiago, 2015). The influence of price value to internet-based service usage also studied by (Gaitan et al., 2015) about internet banking, (Nugroho et al., 2017) about mobile payment, (Azis and Kamal, 2016) about e-commerce and mobile applications (Kit et al, 2014). Accordingly, this study formulates hypothesis as follows.

H4: Price/value significantly affects behavioral intention to use mobile banking.

\section{Hedonic Motivation}

Hedonic motivation refers to the level of pleasure or pleasure gained from using mobile banking (Venkatesh et al., 2012). Research conducted by Kit et al (2014) states that hedonic motivation has a positive effect on interest in using mobile banking by referring to pleasant user experience or pleasure when using technology-based applications. The use of technology is driven by aspirations to engage in fun and entertaining activities. Previous studies of (Magni, Taylor, and Venkatesh, 2010; and Kit, et al., 2014) state that hedonic motivation influences interest in using mobile banking. Accordingly, this study formulates hypothesis as follows.

H5: Hedonic motivation significantly affects behavioral intention to use mobile banking.

Habit

Based on the research conducted by Azis and Kamal (2016) in the context of e-commerce, habits are shown to know consumer habits in using the internet to shop online in everyday life. Habit is one of the key constructs and explains the use directly and indirectly through intention to use (Gaitan et al., 2015).

Also, Lewis et al. (2013) found that habits have a positive influence on the behavior of technology use in the classroom. Previous research (Gaitan et al., 
2015; Kit et al., 2014; Azis and Kamal, 2016; Baptista and Tiago, 2015; and Lewis et al., 2013) explained that habits have a positive influence on the behavior of using mobile banking. Referring to the above theories, this study formulates hypothesis as follows.

H6: Habit significantly affects the reuse behavior of using mobile banking.

Facilitating Condition

Facilitating conditions are similar to perceived behavioral control from TPB, $\mathrm{TPB}+\mathrm{TAM}$, conditions that facilitate the MPCU and compatibility of IDT ( $\underline{\mathrm{Yu}}$, 2012). Safety is also needed because users who have access to a range of favorable facilitation conditions, such as the online mobile banking, demo or online chat tutorial, will have a greater intention to use mobile banking (Baptista and Tiago, 2015; Yu, 2012; Nugroho et al., 2017; Foon and Fah, 2011; and Tarhini et al., 2015) stated that facilitating conditions have a positive effect on the behavior of mobile banking usage. Therefore, this study formulates hypothesis as follows.

H7: Facilitating condition significantly affects the reuse behavior of using mobile banking.

\section{Perceived Credibility}

Some studies about the adoption of mobile banking have discussed that users will refuse or refuse to use mobile banking for various reasons related to perceived risk (Riquelme and Rios, 2010; Natarjan et al., 2010) or perceived credibility (Luarn and Lin, 2005).

Risk perception is also a very important consideration in acquiring new technologies or services (Laforet and Lin, 2005). Some studies have used perceptions of credibility not only in the context of mobile banking (Luarn and Lin, 2005; Riquelme, 2010; Yu, 2012), internet banking (Wang et al, 2003; Tarhini et al. 2015) but also on mobile payment (Nugroho et al., 2017). Based on previous research, perceived credibility represents individual security, privacy, risk and trust regarding the use of mobile banking, as in Yu's (2012) study. Previous research (Yu, 2012; Tarhini, 2015; Jeong and Yoon, 2013; and Abuzwida et al., 2017) stated that perceptions of credibility had a positive effect on influencing people's interest to use mobile banking. Therefore, this study formulates hypothesis as follows.

H8: Perceived credibility significantly affects behavioral intention to use mobile banking.

\section{Perceived Self-Efficacy}

According to Brown et al. (2003), the perception of self-efficacy is not a direct determinant in influencing user behavior in adopting mobile banking. 
Page 88-106

However, several studies that discuss mobile banking (Luarn and Lin, 2005; Sripalawat et al., 2011; $\underline{\text { Yu, 2012) }}$ support the perception of self-efficacy as a determinant in influencing user behavior towards mobile banking adoption.

Meanwhile, another factor that significantly influences mobile banking adoption is self-efficacy (Jeong and Yoon, 2013). Luar and Lain (2005) state that the perception of self-efficacy has a positive influence on the perceived ease of users and intentions in using cellular services. Moreover, according to Nair and Fassal (2017), the perception of self-efficacy has a positive effect on the usefulness of devices. ( $\mathrm{Yu}, 2012$; AbuShanab, Pearson and Setterstom, 2010; Jeong and Yoon, 2013; Nair and Fassal, 2017; and Sripalawat et al., 2011) states that perceptions of self-efficacy influence the behavior of using mobile banking. Referred to the theories above, this study formulates hypothesis as follows:

H9: Perceived self-efficacy significantly affects the reuse behavior of using mobile banking.

\section{Behavioural Intention}

The intention to use technology is a central concept in TAM and UTAUT ( and Setyohadi, 2016). In this study, the behavioral intention is a dependent variable as well as an intermediary variable. Behavior intention is used to draw how much the user wants to use mobile banking for transactions and other financial activities, while user behavior is used to explain the intensity of users in using mobile banking every day (Azis and Kamal, 2016). Therefore, the relationship between behavioral intention and user behavior on mobile banking adoption can be stated in the hypothesis H10. The research model can be seen in Figure 1.

H10: Behavioral intention significantly affects the reuse behavior of using mobile banking.

\section{METHODS}

The type of data in this study is primary data collected from respondents' answers to through distributing the questionnaire. The data is collected from customers who have used the mobile banking application in the area Jabodetabek (Jakarta, Bogor, Depok, Tangerang, and Bekasi) Indonesia. It is because Jabodetabek is the biggest internet users in Indonesia. According to the results of a survey conducted by the Indonesian Internet Service Providers Association (APJII, 2016), the majority of internet users in Indonesia were on Java with a total user of 86,339,350 users or around $65 \%$ of the total internet usage (APJII, 2016). Therefore, the Jabodetabek area is representative in reflecting the interests and behavior of using mobile banking. The sampling method was convenience sampling as one of non-probability sampling type. Through this method, 205 respondents meet the criteria and have selected as the samples. This study uses the 
Partial Least Square (PLS) approach with Smart PLS software ver. 3.2.7.

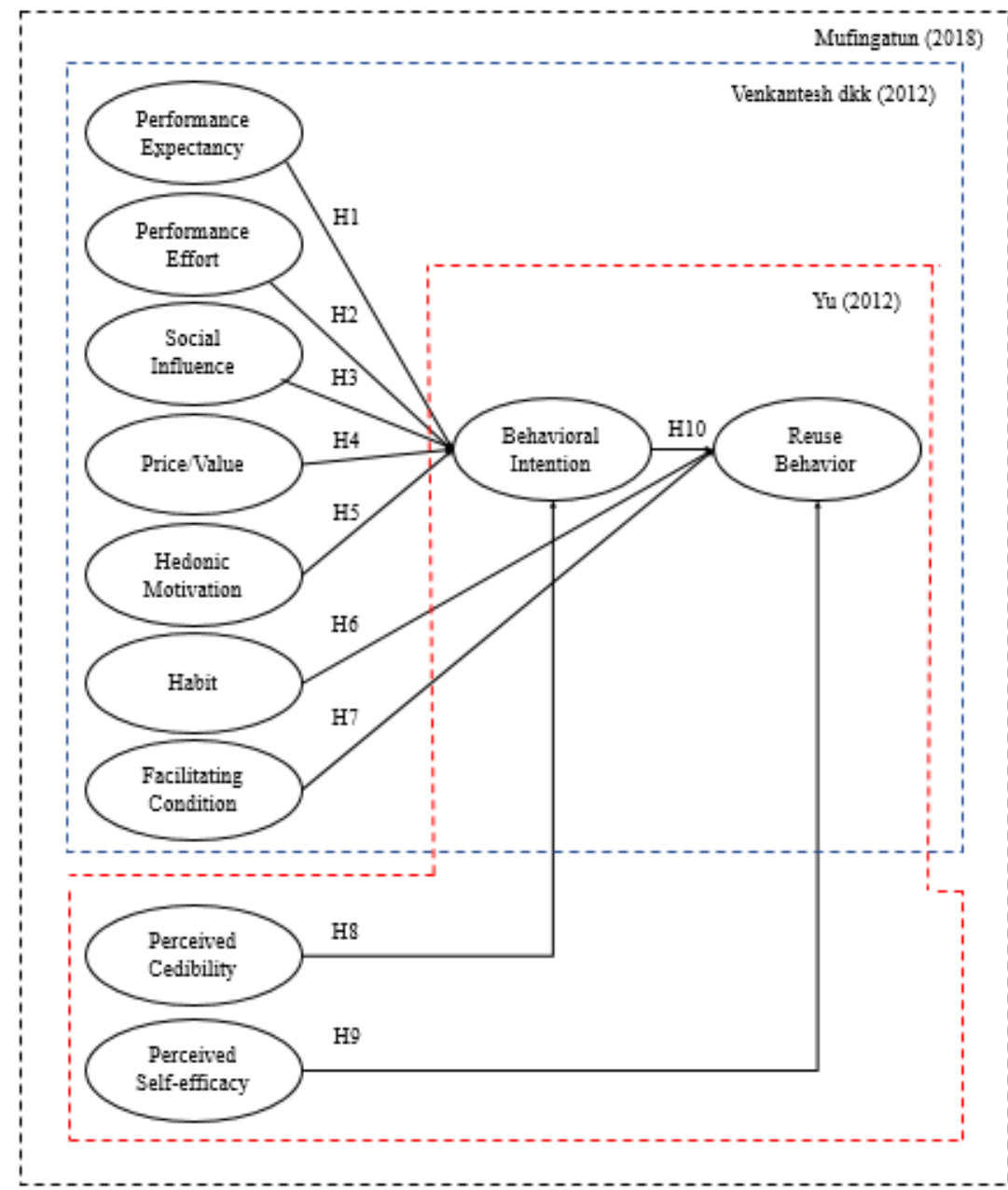

Source: Venkatesh et al., (2012) and Yu, Chian-So. (2012)

Figure 1. Research Model

\section{RESULT AND DISCUSSION}

\section{Outer-Model Test}

In this research, thirty samples were tested to be tested on large samples. In testing the convergent validity in the first literacy three variables must be eliminated because the indicators SI4, FC1 and FC2 are less than 0.70 , then do the test again. The second literacy result states that all indicators have a value $>0.70$ so that they can proceed to the next test. In the discriminant validity test, the results of cross loading estimation show that the construct correlation value with the indicator is greater than the value of the correlation with other constructs.

The construct reliability test is stated to be reliable if the composite reliability and Cronbach alpha values are greater than 0.70 (Latan and Ghozali, 2012). Meanwhile, the results of the reliability test show the Cronbach's alpha and composite reliability values for all constructs are above the value of 0.70 . 
BISMA (Bisnis dan Manajemen)

Volume 12 Issue 2, April 2020

E-ISSN 2549-7790, P-ISSN 1979-7192

Page 88-106

\section{Inner-Model Test}

Table 1. Result of Aj. R Square, $\mathrm{Q}^{2}$ and GoF Test

\begin{tabular}{|c|c|c|}
\hline Test & Estimate & Result \\
\hline Adj. R-Square $\rightarrow$ BI & 0.405 & $\begin{array}{l}\text { The variables PE, EE, SI, PV, and PC can } \\
\text { explain } 40.5 \% \text {. The rest of } 59.5 \% \text { is } \\
\text { influenced by other factors. }\end{array}$ \\
\hline Adj. R-Square BI $\rightarrow$ USE & 0.336 & $\begin{array}{l}\mathrm{BI}, \mathrm{H}, \mathrm{FC} \text { and PSE variables can explain } \\
33.6 \% \text {. The remaining } 66.4 \% \text { is influenced } \\
\text { by other factors. }\end{array}$ \\
\hline Predictive Relevance $\mathrm{Q}^{2} \rightarrow \mathrm{BI}$ & 0.262 & $\begin{array}{c}\text { The variables PE, EE, SI, PV, and PC can } \\
\text { predict the BI value of } 26.2 \% \text {. }\end{array}$ \\
\hline $\begin{array}{l}\text { Predictive Relevance } Q^{2} \text { BI } \rightarrow \\
\text { USE }\end{array}$ & 0.197 & $\begin{array}{l}\text { BI, H, FC and PSE variables can predict } \\
\text { USE values of } 19.7 \% \text {. }\end{array}$ \\
\hline GoF & 0.522 & $\begin{array}{l}\text { The overall model is said to be fit because of } \\
\qquad 0.522>0.36 .\end{array}$ \\
\hline
\end{tabular}

Source: SmartPLS Output, Data Processed

After testing the measurement model in Partial Least Square (PLS), a structural model was tested. The structural model in PLS is evaluated using the coefficient of determination $\left(\mathrm{R}^{2}\right)$ for the dependent construct. Meanwhile, the path or $p$-values coefficient values for each path is calculated for inter-construct significance tests in the structural model, as well as predictive relevance $\left(\mathrm{Q}^{2}\right)$. Detailed results can be seen in table 1 .

\section{Hypothesis Test}

According to Hass and Lehner (2009), the path coefficient values in the range of -0.1 to 0.1 are considered insignificant, a value greater than 0.1 is a significant value and is directly proportional, and a value smaller than $-0,1$ is a significant value and inversely proportional. The next consideration is to use a significance value, minimal at $\alpha=0.05$ so that it is considered significant if the value of the $\mathrm{P}$-value is less than 0.05 . Therefore, the hypothesis is accepted if the path coefficient value is greater than 0.0 and the P-value is smaller than 0.05. Therefore, Table 2 shows that four out of the ten hypotheses proposed in this study are rejected $\left(\mathrm{H}_{4}, \mathrm{H}_{5}, \mathrm{H}_{8}\right.$, and $\left.\mathrm{H}_{9}\right)$ while six hypotheses are accepted $\left(\mathrm{H}_{1}, \mathrm{H}_{2}\right.$, $\mathrm{H}_{3}, \mathrm{H}_{6}, \mathrm{H}_{7}$, and $\mathrm{H}_{10}$ ).

\section{Discussion}

The results of the study indicate that performance expectancy (PE) has a significant positive effect on behavioral intention (BI). This can be seen from the value of p-values which are less than 0.05 , which is 0.002 . It explains that the higher the level of customer confidence in using mobile banking will improve its performance in transactions and other facilities and the greater the interest of customers in utilizing mobile banking. This result also shows that the Jabodetabek 
community of mobile banking users feel the use of mobile banking can enable them to work faster and admit it useful for their lives to increase their productivity.

Table 2. Test Results on the Research Model

\begin{tabular}{|c|c|c|c|c|}
\hline Hypothesis & Influence & $\begin{array}{c}\text { Path } \\
\text { Coefficient }\end{array}$ & $\begin{array}{c}\mathbf{P} \\
\text { Values }\end{array}$ & Result \\
\hline H1 & $\begin{array}{l}\text { Performance Expectancy } \rightarrow \text { Behavioral } \\
\text { Intention }\end{array}$ & 0.230 & 0.002 & Significant \\
\hline $\mathrm{H} 2$ & Effort Expectancy $\rightarrow$ Behavioral Intention & 0.218 & 0.002 & Significant \\
\hline $\mathrm{H} 3$ & Social Influence $\rightarrow$ Behavioral Intention & 0.137 & 0.017 & Significant \\
\hline $\mathrm{H} 4$ & Price / Value $\rightarrow$ Behavioral Intention & 0.113 & 0.093 & $\begin{array}{c}\text { Not } \\
\text { Significant }\end{array}$ \\
\hline H5 & $\begin{array}{l}\text { Hedonic Motivation } \rightarrow \text { Behavioral } \\
\text { Intention }\end{array}$ & 0.105 & 0.198 & $\begin{array}{l}\text { Not } \\
\text { Significant }\end{array}$ \\
\hline H6 & Habit $\rightarrow$ Reuse Behavior & 0.171 & $\mathbf{0 . 0 2 0}$ & Significant \\
\hline $\mathrm{H} 7$ & Facilitating Condition $\rightarrow$ Reuse Behavior & 0.180 & 0.014 & Significant \\
\hline $\mathrm{H} 8$ & $\begin{array}{l}\text { Perceived Credibility } \rightarrow \text { Behavioral } \\
\text { Intention }\end{array}$ & 0.105 & 0.118 & $\begin{array}{c}\text { Not } \\
\text { Significant }\end{array}$ \\
\hline H9 & $\begin{array}{l}\text { Perceived Self-Efficacy } \rightarrow \text { Reuse } \\
\text { Behavior }\end{array}$ & 0.035 & 0.657 & $\begin{array}{l}\text { Not } \\
\text { Significant }\end{array}$ \\
\hline H10 & Behavioral Intention $\rightarrow$ Reuse Behavior & 0.370 & 0.000 & Significant \\
\hline
\end{tabular}

Source: SmartPLS Output, Data Processed

This supports the study of Venkatesh et al., (2003) that stated performance expectancy is a strong predictive variable from the use of information systems. So as Yu's (2012) research, performance expectancy affects consumer intentions in adopting mobile banking. The results of this study are also following the research conducted by Nugroho et al. (2017), AbuShanab, Pearson and Setterstom (2010), Venkatesh et al. (2012), Azis and Kamal (2016), Pertiwi and Ariyanto (2017), Foon and Fah (2011), Gaitan et al (2015), Tarhini, et al. (2015), Baptista and Tiago (2015), and Kit, et al. (2014).

Furthermore, based on the results of the study, effort expectancy (EE) has a significant positive effect on behavioral intention (BI). This can be seen from the value of $\mathrm{p}$-values which are less than 0.05 , which is 0.002 . The results obtained in this study are positive which means that the high confidence of people to use mobile banking can increase the effort needed in using mobile banking and create greater interest in using mobile banking. This shows that customers are familiar with the use of mobile banking, so the interaction that occurs is very clear and has a good understanding of its use. This explains that user-friendliness influences customer interest in Jabodetabek in using mobile banking that implies the factor of effort expectancy is affected in this study. According to Nugroho et al (2017) stated that when users feel that mobile banking is easy to use and does not require much effort, then they have high expectations for the expected performance. The results of this study are in line with the results of Rema and Setyohadi (2016), Abushanab et al (2010), Foon and Fah (2011), Kit et al (2014), and Azis and 
Kamal (2016). It can be concluded that if a customer believes in the use of mobile banking to be able to reduce the business (time and time) needed to fulfill the use of mobile banking, the customer's tendency to use mobile banking continuously will increase.

Based on the results of the study indicate that social influence (SI) has a significant positive effect on behavioral intention (BI). This can be seen from the value of $\mathrm{p}$-values which are less than 0.05 , which is 0.017 . This shows that with the environment of customers who tend to use mobile banking it will affect them to use mobile banking, not from their family or friends who suggest but they have seen the convenience felt by people who have used it so that it can help increase productivity. Social influence is an influential variable that is natural because a very large environmental influence encourages someone to use technology ( $\underline{\text { Azis }}$ and Kamal, 2016). This result is in line with Yu (2012), AbuShanab et al (2010), Foon and Fah (2011) and Azis and Kamal (2016). The surrounding environment that supports the use of mobile banking will increase customers to use the system continuously and for a long time.

Based on the results of the study indicate that price/value (PV) does not affect behavioral intention (BI). This can be seen from the value of $p$-values greater than 0.05 , which is 0.093 . The cost of using mobile banking is relatively cheap when compared to the benefits obtained. But this advantage is only a bonus obtained from its use because low costs do not affect the interest in using mobile banking in Jabodetabek. If the perceived benefits of the application are high, it will affect users to adopt the mobile banking application. The main purpose of its use is because it is useful in increasing productivity. The results of this study are in line with Pertiwi and Ariyanto (2017), Nugroho et al (2017), Kit et al (2014), Azis and Kamal (2016), and Baptista and Tiago (2015).

Based on the results of the study indicate that hedonic motivation (HM) does not affect behavioral intention (BI). This can be seen from the value of $\mathrm{p}$ values greater than 0.05 , which is 0.198 . This explains that for Jabodetabek customers the use of mobile banking is fun and convenient. However, this does not affect the interest in using mobile banking. Without the pleasure that can be obtained, customers in Jabodetabek will continue to feel the benefits and pleasure because they feel very useful, especially in increasing their productivity. In a study conducted by Gaitan et al. (2015) stated that hedonic motivation does not affect the behavior intention, technological cases where utilitarian and hedonic benefits exist and both will be very important determinants from the user side, but if the technology is more oriented to hedonic values this will have a greater impact on the intention to adopt it. The results of the study are in line with Azis and Kamal (2016), Gaitan et al (2015), Nugroho et al (2017) and Pertiwi and Ariyanto (2017).

The results of the study show that habit $(\mathrm{H})$ has a significant positive effect 
on reuse behavior (USE). It can be seen from the value of p-values that are less than 0.05 , which is 0.020 . This is supported by the majority of respondents of this study are users who have used mobile banking for more than 2 years so that this becomes a habit for users in Jabodetabek. This habit makes them addicted, so using mobile banking is felt like a necessity when conducting non-cash banking transactions. The research conducted by Azis and Kamal (2016) in the context of e-commerce, habits are shown to know consumer habits in using the internet to shop online in everyday life. Habit is one of the key constructs and explains the use directly and indirectly through intention to use (Gaitan et al., 2015). This result is in line with the research conducted by Gaitan et al. (2015), Kit et al (2014), Azis and Kamal (2016), Baptista and Tiago (2015), and Lewis et al (2013).

Then, based on the results of the study, facilitating conditions (FC) has a significant positive effect on reuse behavior (USE. This can be seen from the value of p-values which is less than 0.05 , which is 0.014 . Facilities owned by customers and good knowledge of their use, customers will use mobile banking in banking matters. The results obtained in this study means that good supporting conditions will increase customer interest in using mobile banking. In other words, if customers have facilities such as smartphones, and internet connections equipped with $3 \mathrm{G}$ or $4 \mathrm{G}$ networks and knowledge possessed by customers, the behavior of using mobile banking will increase. With the high facilitating condition, the user tends to use mobile banking regularly. The research conducted by $\underline{\mathrm{Yu}(2012)}$ states that facilitating conditions have a positive effect on the behavior of using mobile banking. Facilitating conditions are operationalized as the level at which someone believes that he has the context needed to support mobile banking use. The results of this study are in line with $\underline{\mathrm{Yu}, 2012}$; Nugroho et al., 2017; 2011; and Tarhini et al., 2015).

Furthermore, it showed that the perceived credibility (PC) variable did not affect behavioral intention (BI) variables. This can be seen from the value of $\mathrm{p}$ values greater than 0.05 , which is 0.118 . The perceived credibility in this research is the extent to which someone believes that mobile banking is free from security and privacy issues. Customers in Jabodetabek feel safe and their privacy is maintained when using mobile banking, but this does not affect customers in using mobile banking. According to Arahita and Jurry (2015) in his research stated that perceived credibility does not affect behavioral intention on mobile BCA. Customer perceptions of risk, security and high uncertainties such as data loss and misuse of personal information will be a barrier for customers to reuse BCA mobile. The results of the study are in line with Nugroho et al. (2017), Arahita and Jurry (2015), Karma et al. (2014), Kazi and Mannan (2013), and Safeena et al. (2011).

Conversely, based on the results of the study, perceived self-efficacy (PES) does not affect reuse behavior (USE). This can be seen from the value of $p$-values 
greater than 0.05, which is 0.657. Customers in Jabodetabek will find it helpful to use a guidebook in the form of a handbook, soft book, or explanation on social media rather than assistance with other people because they feel insecure if assisted by others especially in banking matters. The results show no effect means that without the ability or assistance that is obtained by people around and others. Customers will continue to use mobile banking and will use continuously for banking matters in their daily lives. The result support previous research conducted by Brown et al. (2003) which states that perceived self-efficacy does not affect reuse behavior.

Meanwhile, the results of the study indicate that behavioral intention (BI) has a significant positive effect on reuse behavior (USE). The interest in using mobile banking in this study relates to one's interest in using a system continuously. Behavior intention is a factor that reflects the interest in behaving or desires of consumers to behave using or adopting the internet influenced by the conditions of existing facilities and also the habit of using the internet itself (Baptista and Tiago, 2015). Customers in Jabodetabek use mobile banking because they feel the benefits and ease of use. Besides, without interest in using mobile banking, customers will not use mobile banking services. These positive research results indicate that bank customers in Jabodetabek predict and plan to continue using mobile banking in the future. This result supports the research of Rema and Setyohadi (2016), Pertiwi and Ariyanto (2017), Yu (2012), Nugroho et al (2017), Abushanab et al (2010), Foon and Fah (2011), Gaitan et al (2015), Kit et al (2014), as well as Azis and Kamal (2016).

\section{CONCLUSION}

The results of the study prove that the research model compiled based on UTAUT2 with modification of the model of the addition of two perceived credibilities (PC) and perceived self-efficacy (PSE) explained the behavioral intention (BI) and reuse behavior (USE) of mobile banking applications in Jabodetabek. The results of the significance test on the path of behavioral intention (BI) show that the variable performance expectancy (PE), effort expectancy (EE), and social influence (SI) influence behavioral intention (BI). Whereas price/value (PV), hedonic motivation (HM) and perceived credibility (PC) variables do not affect behavioral intention (BI). The significance test results on the path of reuse behaviour (USE) show that habit variables $(\mathrm{H})$, facilitating conditions (FC), and behavioral intention (BI) influence reuse behavior (USE). Meanwhile, the perceived self-efficacy (PSE) doesn't affect reuse behavior (USE).

The implication of this research is this researchable to add insight, contribution to the development of knowledge in the field of information systems especially in the interests and behavior of the use of mobile banking. Therefore, it 
is expected that there will further research on the interests and behavior of using mobile banking with more complex factors which this research can be used as an essential reference. For businesses in the banking sector, this research is expected to provide information about customer interests and behavior of mobile banking can be used as a reference for decision making in banking strategy, as a way to improve the service quality of mobile banking services for customers. Moreover, this research is expected can educate the public about mobile banking services that able to provide convenience in conducting banking transactions, in this case, non-cash transactions. Hence, the recommendation to the banking sector is to provide highly secured mobile banking services for the customer related to the high-security risk of the mobile banking application and to improve their risk mitigation when the problems occurred during providing the services.

\section{REFERENCES}

Abushanab, Emad, J.Michael Perason and Andrew J.Setterstrom. (2010). Internet Banking and Customers' Acceptance in Jordan: The Unified Model's Perspective. Communications of the Association for Information Systems: Article 26, Volume 26. http://doi.org/10.17705/1CAIS.02623

Abuzwida, Bashir, Zulkiplie Abd Ghani and Faizal Bin Kasmani. (2017). Study Of Relationship Between Utuat Factors and Intention Towards Usage EManagement In Libyan Petroleum Industry. International Journal of Management, Innovation \& Entrepreneurial Research EISSN: 2395-7662, Vol. 3, No 2, September 2017, pp 61-66. http://doi.org/10.18510/ijmier.2017.322

APJII. (2016). Buletin APJII Edisi 05 November 2016. Access on website APJII : https://apjii.or.id/content/read/104/275/BULETIN-APJII-EDISI-05--November-2016 /on 25 November 2017.

Arahita, Ceva Lavenja and Jurry Hatammimi. (2015). Factors Affecting the Intention of Reuse. International Journal of Research in Business and Social Science IJRBS ISSN: 2147-4478 Vol.4 No.4, 2015 Mobile Banking Service. http://doi.org/10.20525/ijrbs.v4i4.15

Aziz, Elvira and Ragil Muhammad Kamal. (2016). Adoption of A Consumer Technology Online Shopping with Model MSMEs Unified Theory of Acceptance and Use of Technology 2.CR Journal Vol.02 No.01. http://doi.org/10.34147/crj.v2i1

Baptista, Goncalo and Tiago Oliveira. (2015). Understanding mobile banking: The unified theory of acceptance and use of technology combined with cultural moderators. Computers in Human Behavior 50 (2015) 418-430. http:/doi.org/10.1016/j.chb.2015.04.024 
Page 88-106

Bhimasta, Raden Agoeng. (2017). Determinant Factors Of Consumer Adoption Toward Intention To Use Mobile Wallet: A Case Study Indonesian Y Generation. S2 Thesis, Univeritas Atma Jaya Yogyakarta.

Brown, I., C. Zaheeda, D. Douglas, and S. Stroebel. (2003). Cell phone banking: predictors of adoption in South Africa - an exploratory study. International Journal of Information Management, Vol. 23: 381-394. http://doi.org/10.1016/S0268-4012(03)00065-3

Ferdiansyah, Irvan and Putu Wuri Handayani. (2011). Penentuan CSF Pada Website Internet Banking Ditinjau dari Aspek Kebutuhan Pengguna Sebagai Nasabah Individual dengan Studi Kasus BCA, Bank Mandiri, Dan BNI. Journal of Information Systems, Volume 7, Issues 1, April 2011. http://doi.org/10.21609/jsi.v7i1.295

Foon, Yeoh Sok and Benjamin Chan Yin Fah. (2011). Internet Banking Adoption in Kuala Lumpur: An Application of UTAUT Model. International Journal of Business and Management: Vol. 6, No.4. http://doi.org/10.5539/ijbm.v6n4p161

Gaitan, Jorge Arenas-Gaitan, Begona Peral-Peral and Maria Angeles RamonJeronimo. (2015). Elderly and Internet Banking: An Application of UTAUT2. Journal of Internet Banking and Commerce, April 2015, vol. 20, no. 1.

Hass, N., and Lehner, F. (2009). Knowledge Management Success Factors Proposal of an Empirical Research. Proceedings of the 10th European Conference on Knowledge Management.

IFC (2010). Mobile Banking in Indonesia. Access from https://www.ifc.org/wps/wcm/connect/16cc33cf-f3d5-44bc-b439ead8991cbcc4/Mobile\%2BBanking\%2BFinal\%2BReport.pdf?MOD=AJPE RES\&CVID=j1FGbYr / on 03 March 2020.

Jeong, Bong-Keun and Tom E Yoon. (2013). An Empirical Investigation on Consumer Acceptance of Mobile Banking Services. Business and Management Research Vol. 2, No. 1; 2013. http://doi.org/10.5430/bmr.v2n1p31

Karma, N.G., Ibrahim, S.B. and Ali, A.H. (2014). Key factors affecting mobile banking adoption among banks' customers in Sudan. International Journal of Liberal Arts and Social Science, 2(6), 112-122.

Kazi, A.K. and Mannan, M.A. (2013). Factors affecting adoption of mobile banking in Pakistan: Empirical Evidence. International Journal of Research in Business and Social Science, 2(3), 54-61. http://doi.org/10.20525/ijrbs.v2i3.73 
Kit, A. K., Ni, A. H., Badri, E. N., and Yee, T. K. .(2014). UTAUT2 influencing the behavioural intention to adopt mobile applications.Bachelor Thesis. Universiti Tunku Abdul Rahman.

Laforet, S. and X. Li. (2005). Consumers' attitudes toward online and mobile banking in China. International Journal of Bank Marketing, Vol. 23, No. 5: 362-380, 2005. http://doi.org/10.1108/02652320510629250

Latan, H., and Ghozali, I. (2012). Partial Least Squares: Konsep, Teknik, dan Aplikasi Menggunakan Program SmartPLS 2.0 M3. Semarang: Badan Penerbit Universitas Diponegoro.

Lewis, C. C., Fretwell, C. E., Ryan, J., \& Parham, J. B.(2013). Faculty use of established and emerging technologies in higher education: A unified theory of acceptance and use of technology perspective. International Journal of Higher Education, 2(2), 22-34. http://doi.org/10.5430/ijhe.v2n2p22

Luarn, P. and H. H. Lin. (2005). Toward an understanding of the behavioural intention to use mobile banking. Computers I Human Behavior, Vol. 21: 873-891. http://doi.org/10.1016/j.chb.2004.03.003

Magni, Massimo, M. Susan Taylor and Visnawath Venkatesh. (2010). 'To play or not play': A cross-temporal investigation using hedonic and instrumental perspective to explain user intentions to explore a technology. Int. J.Human$\begin{array}{llll}\text { Computer } & \text { Studies 68(2010) 572-588. }\end{array}$ http://doi.org/10.1016/j.ijhcs.2010.03.004

Mars Indonesia. (2013). Awareness \& Penetrasi Mobile banking Melonjak Tinggi. Access from Website Newsletter Mars Indonesia: https://newsletter.marsindonesia.com/2013/02/06/awareness-penetrasimobile-banking-melonjak-tinggi/ on 11 November 2017.

Nair, Ranjini S. and Shaniba Fasal. (2017). Mobile Banking and its Adopting Challenges. International Journal of Computer Applications (0975 - 8887) Volume 160 - No 4, February 2017. http://doi.org/10.5120/ijca2017913036

Natarjan, T., S. A. Balasubrmanian, and S. Manickavasagam. (2010). Customer's choice amongst self-service technology (SST) channels in retail banking: A study using analytical hierarchy process (AHP). Journal of Internet Banking and Commerce, Vol. 15, No. 2: 1-16.

Nayak, Nitin. Vikas Nath and Nancy Goel. (2014). A Study Of Adoption Behaviour Of Mobile Banking Services By Indian Consumers. International Journal of Research in Engineering \& Technology (IMPACT: IJRET) $\operatorname{ISSN}(E)$ : 2321-8843; ISSN(P): 2347-4599 Vol. 2, Issue 3, Mar 2014, 209222.

Nugroho, Priyatmoko, Wing Wahyu Winarmo and Rudy Hartanto.(2017). FaktorFaktor yang Mempengaruhi Niat Menggunakan Mobile payment dengan 
Pendekatan Extended The Unified Theory of Acceptance and Use of Technology. Jurnal CITEE 2017.

Otoritas Jasa Keuangan (OJK). (2015). Bijak Ber-eBanking. Access on website OJK :https://ojk.go.id/Files/box/buku\%20bijak\%20ber-ebanking.pdf/ on 25 November 2017.

Pertiwi, Ni Wayan Dewi Mas Yogi and Dodik Ariyanto. (2017). Penerapan Model UTAUT2 untuk Menjelaskan Minat dan Perilaku Penggunaan Mobile Banking Di Kota Denpasar. E-Jurnal Akuntansi Universitas Udayana Vol.18.2. Februari (2017): 1369-1397, ISSN: 2302-8556.

Putra, Muhammad Dhandy Riyandra. (2015). Analisis Keberterimaan Aplikasi Mobile Banking: Menggunakan Pendekatan Unified Theory of Acceptance and Use of Technology (UTAUT) yang Dimodifikasi. Thesis: Univeristas Gadjah Mada.

PWC (2018). PWC Survey : Digital Banking in Indonesia 2018. Access from : https://www.pwc.com/id/en/publications/assets/financialservices/digitalbanking-survey-2018-pwcid.pdf / on 03 March 2020.

Rahmayani, Indah. (2015). Indonesia Raksasa Teknologi Digital Asia. Access from Website Kominfo :https://kominfo.go.id/content/detail/6095/indonesia-raksasa-teknologidigital-asia/0/sorotan_media on 11 November 2017.

Rema, Yasinta Oktaviana L. and Djoko Budianto Steyohadi. (2016). FaktorFaktor yangg Mempengaruhi Penerimaan Mobile Banking Studi Kasus: Bri Cabang Bajawa. Seminar Riset Teknologi Informasi (SRITI).

Riquelme, H. and R. E. Rios. (2010). The moderating effect of gender in the adoption of mobile banking. International Journal of Bank Marketing. Vol. 28, No. 5: 328.

Safeena, R., Hundewale, N., dan Kamani, A. (2011). Customer's adoption of mobile commerce: a study on the emerging economy. International Journal of e-Education, e-Business, e-Management and e-Learning, 1(3), 228233.341. http://doi.org/0.1108/02652321011064872

Sripalawat, Jiraporn, Mathupayas Thongmak \& Atcharawan Ngramyarn. (2011). M-Banking in Metropolitan Bangkok and a Comparison with other Countries. Journal of Computer Information Systems, 51:3, 67-76. http://doi.org/0.1080/08874417.2011.11645487

Tarhini, Ali, Mazen El-Masri, Maged Ali, and Alan Serrano. (2016) .Extending the UTAUT model to understand the customers' acceptance and use of internet banking in Lebanon A structural equation modelling approach, 
Information Technology \& People, Vol. 29 Iss 4 pp. 830 - 849. http://doi.org/10.1108/ITP-02-2014-0034

Tempo. (2016). Pengguna Mobile Banking di Indonesia Masih Rendah. Access from Website Tempo.co : https://bisnis.tempo.co/read/811653/penggunamobile-banking-di-indonesia-masih-rendah/ on 11 November 2017

Venkatesh, Viswanath, James Y. L. Thong, and Xin Xu. (2012) . Consumer Acceptance and Use of Information Technology: Extending The Unified Theory of Acceptance and Use of Technology. MIS Quarterly Vol. 36 No.1. http://doi.org/10.2307/41410412

Venkatesh, V., M. G. Morris, G. B. Davis, and F. D. Davis. (2003) . User acceptance of information technology: Toward a unified view. MIS Quarterly, Vol. 27, No. 3: 425-478, 2003. http://doi.org/10.2307/30036540

Wikipedia (2020). List of banks in Indonesia. Access from https://en.wikipedia.org/wiki/List_of_banks_in_Indonesia/ on 03 March 2020 .

Wang, Y. S., Y. M. Wang, H. H. Lin, and T. I. Tang. (2003). Determinants of user acceptance of Internet banking: an empirical study. International Journal of Service Industry Management, Vol. 14, No. 5: 501-519. http://doi.org/ $\underline{10.1108 / 09564230310500192}$

Yu, Chian-So. (2012). Factors Affecting Individuals to Adopt Mobile Banking Empirical Evidence From the UTAUT Model. Journal of Electronic Commerce Research, Vol. 13, No.2 : 104-121. 